\title{
$\beta$-inducible gene-h3 promotes human breast carcinoma cell metastasis by activating the phosphatidylinositol 3-kinase/protein kinase B signaling pathway
}

\author{
JIAXIN ZHANG ${ }^{1}$ and ZHAOJIANGBO LI ${ }^{2}$ \\ ${ }^{1}$ Department of Breast Surgery, Weifang People's Hospital, Weifang, Shandong 261000; \\ ${ }^{2}$ Department of General Surgery Ward Two, Pingdu People's Hospital, Qingdao, Shandong 266700, P.R. China
}

Received January 3, 2017; Accepted November 17, 2017

DOI: $10.3892 /$ etm.2018.5786

\begin{abstract}
Metastatic breast cancer is one of the most common metastatic tumors. Although studies have validated the role of $\beta$-inducible gene-h3 ( $\beta$ ig-h3) in human biology and disease, the detailed mechanisms mediated by $\beta$ ig-h3 in breast carcinoma metastasis remain unclear. Thus, the present study investigated the role and potential mechanism of $\beta$ ig-h 3 during breast carcinoma cell metastasis. The results indicated that the upregulation of $\beta$ ig-h3 significantly promotes the growth and inhibits the cisplatin-induced apoptosis of breast carcinoma cells. It was also demonstrated that $\beta$ ig-h 3 promoted the migration and invasion of human breast carcinoma cells in vitro and in vivo. Furthermore, the results demonstrated that Big-h3 upregulated the overall expression and phosphorylation of phosphatidylinositol 3-kinase (PI3K) and protein kinase $\mathrm{B}$ (Akt) in human breast carcinoma cells. By contrast, $\beta$ ig-h3 knockdown reversed the $\beta$ ig-h3-mediated characteristics of breast carcinoma cells. Thus, the current study demonstrated that the PI3K/Akt signaling pathway serves a role in Big-h3-induced human breast cancer cell metastasis and that Big-h3 transfection enhances the metastatic potential of human breast carcinoma cells via the PI3K/Akt signaling pathway. These observations contribute to the understanding of the potential mechanism of human breast carcinoma cell growth and metastasis and suggest that $\beta$ ig-h3 may be a promising therapeutic target for the treatment of human breast carcinoma.
\end{abstract}

\section{Introduction}

Metastatic breast cancer is one of the most common types of metastatic tumors and affects the health of women around the

Correspondence to: Professor Zhaojianbo Li, Department of General Surgery Ward Two, Pingdu People's Hospital, 112 Yangzhou Road, Qingdao, Shandong 266700, P.R. China

E-mail: lizhaojianboprof@163.com

Key words: $\beta$-inducible gene-h3, breast carcinoma, metastasis, phosphoinositide 3-kinase/protein kinase B world (1). The mortality rate of patients with breast carcinoma is high due to local invasion and distant metastasis and $>30 \%$ of patients with breast carcinoma develop metastasis during progression of their disease $(2,3)$. The 5 -year overall survival rate of patients with breast cancer is $4-28 \%$ and reports have indicated that the incidence of breast cancer in young women is growing and is frequently metastatic following diagnosis $(4,5)$. Therefore, it is critical to analyze the potential mechanism(s) associated with local invasion and distant metastasis to improve the 5-year overall survival rate and prognosis of patients with breast carcinoma $(6,7)$.

Transforming growth factor (TGF)- $\beta$-inducible gene-h3 ( $\beta$ ig-h3) is highly expressed in various types of tumors in humans and is associated with the growth and metastasis of tumor cells (8-10). $\beta$ ig-h3 encodes a secreted extracellular matrix (ECM) protein and it has been demonstrated that this protein is induced by TGF- $\beta$ in pancreatic cancer cells, subsequently stimulating the growth and invasion of pancreatic cancer cells (11). Furthermore, previous studies have indicated that the ECM protein TGF- $\beta$ ig-h3 promotes colon, gastric and ovarian cancer metastasis by enhancing cell extravasation (12-14).

The phosphatidylinositol 3-kinase (PI3K)/protein kinase $\mathrm{B}$ (Akt) signaling pathway is associated with cancer cell growth and metastasis and serves a role in the development of chemoresistance to platinum-based neoadjuvant chemotherapy (15). In a previous study, measurement of the cellular and molecular responses to lapatinib and Akt inhibitors suggested that they suppress breast cancer growth and aggressiveness (16). In addition, inhibiting PI3K/Akt downregulates the breast cancer resistance protein resensitized MCF7 breast cancer cell line, which promotes the apoptosis of MCF7 cells induced by mitoxantrone chemotherapy (17). Furthermore, a previous study indicated that the binding of matrix metalloproteinase-9-degraded fibronectin to integrin promotes the invasion of breast cancer cells via the focal adhesion kinase-Src-associated extracellular signal-regulated kinase $1 / 2$ and PI3K/Akt/Smad-1/5/8 pathways (18). These results indicate that inhibiting the PI3K/Akt signaling pathway may suppress the growth of breast cancer cells.

The present study investigated the role of $\beta$ ig-h 3 in the progression of breast carcinoma in vitro and in vivo. The 
potential mechanism of $\beta$ ig-h3-mediated growth and aggressiveness of breast carcinoma cells was also investigated. The results indicated that $\beta$ ig-h3 promotes the growth and metastasis of breast carcinoma cells. This may increase understanding of the signaling pathways that are activated during the metastasis of breast cancer cells and indicate that $\beta$ ig-h3 may be a potential therapeutic target to treat breast cancer.

\section{Materials and methods}

Cell culture. The breast cancer cell lines MCF-7, BT474 and SKBR3 and the normal breast cell line MCF-10A were purchased from the American Type Culture Collection (Manassas, VA, USA). All tumor cells were cultured in RPMI-1640 medium supplemented with 10\% heat-inactivated fetal bovine serum (Gibco; Thermo Fisher Scientific, Inc., Waltham, MA, USA), $3 \mathrm{mM}$ L-glutamine, $50 \mu \mathrm{g} / \mathrm{ml}$ gentamicin (Biowhittaker Reagents; Lonza Group, Ltd., Basel, Switzerland) and $1 \%$ penicillin/streptomycin. MCF-10A cells were cultured in a mammary epithelial cell medium (cat. no. 7611, MEpiCM; ScienCell Research Laboratories, Inc., San Diego, CA, USA). MCF-7 is the typical human breast carcinoma cell, therefore, this cell line was chosen for further experiments. All cells were cultured at $37^{\circ} \mathrm{C}$ in $5 \% \mathrm{CO}_{2}$.

Transfection of small interfering RNA (siRNA). A total of $1 \times 10^{8}$ cells (MCF-7, BT474, SKBR3 and MCF-10A) were transfected with either si-Rßig-h3 for knockdown of CHOP (Kd-CHOP) or si-Rvector (Invitrogen; Thermo Fisher Scientific, Inc.). MCF-7 cells $\left(1 \times 10^{6}\right)$ were transfected with 120 pmol si-Rßig-h3 (5'-CCUUUACGAGAC CCUGGGATT-3' and 5'-UCCCAGGGUCUCGUAAAG GTT-3') targeting $\beta$ ig-h3 or si-R vector as a control (Applied Biosystems; Thermo Fisher Scientific, Inc.) using a Cell Line Nucleofector kit L (Lonza Group, Ltd.). Following 48 h transfection, cells were used for further analysis.

Overexpression of PI3K or $\beta$ ig- $h 3$. MCF-7 $\left(1 \times 10^{6}\right)$ cells were cultured until $85 \%$ confluence was reached; media was then removed and cells were washed three times with PBS. MCF-7 cells were then transfected with pLentivirus-PI3K (pPI3K), plentivirus- $\beta$ ig-h3 (pßig-h3, 100 pmol) or plentivirus-vector (pVector, 100 pmol) using Lipofectamine 2000 (Invitrogen; Thermo Fisher Scientific., Inc.) according to manufacturer's instructions. Following $72 \mathrm{~h}$ transfection, cells were used for further analysis.

MTT assay. PI3K- and $\beta$ ig-h3-overexpressed, pVector-transfected, si-R $\beta$ ig-h3-treated or si-Rvector-treated MCF-7 cells $\left(1 \times 10^{3}\right.$ per well) were cultured in 96 -well plates for $48 \mathrm{~h}$ at $37^{\circ} \mathrm{C}$ in triplicate for each condition and pVector-transfected MCF-7 was used as a control. Following incubation, $20 \mu \mathrm{l}$ MTT $(5 \mathrm{mg} / \mathrm{ml})$ in PBS solution was added and dissolved in dimethyl sulfoxide for a further $2 \mathrm{~h}$ at $37^{\circ} \mathrm{C}$. Optical density was measured using an ELISA reader at a wavelength of $450 \mathrm{~nm}$.

Apoptosis assay. ßig-h3-overexpressed, pVector-transfected, si-R $\beta$ ig-h3-treated or si-Rvector-treated MCF-7 cells were grown at $37^{\circ} \mathrm{C}$ with $5 \% \mathrm{CO}_{2}$ until $90 \%$ confluence was reached. Cells were then incubated with cisplatin $(2.0 \mathrm{mg} / \mathrm{ml})$ or PBS for $48 \mathrm{~h}$ at $37^{\circ} \mathrm{C}$, trypsinized and collected. Cells were then washed in cold PBS, adjusted to $1 \times 10^{6}$ cells $/ \mathrm{ml}$ with PBS, labeled with Annexin V-fluoroscein isothiocyanate and propidium iodide (Annexin V-fluoroscein isothiocyanate kit; BD Biosciences, Franklin Lakes, NJ, USA) for $1 \mathrm{~h}$ at $37^{\circ} \mathrm{C}$ and analyzed using a FACScan flow cytometer (BD Biosciences) to assess apoptosis. Treatments were performed in triplicate and the percentage of labeled cells undergoing apoptosis in each group was determined and calculated using a Coulter EPICS XL Flow Cytometer and the results were analyzed using Expo32-ADC v. 1.2B software (Beckman Coulter Inc., Brea, CA, USA).

Cell migration and invasion assays. Sable PI3K-overexpressed, $\beta i g-h$-overexpressed, pVector-transfected, si-R $\beta$ ig-h3-treated or si-Rvector-treated MCF-7 cells were cultured in serum-free medium for $72 \mathrm{~h}$ at $37^{\circ} \mathrm{C}$. Migration and invasion assays were conducted in a 6-well culture plate with Transwell inserts (BD Biosciences). A total of $1 \times 10^{4} \mathrm{MCF}-7$ cells/well were placed into the upper chamber in DMEM supplemented with $5 \%$ FBS for migration assays. For invasion assays, MCF-7 cells $\left(1 \times 10^{4} /\right.$ well $)$ were placed into the upper chamber with a Matrigel-coated membrane in DMEM supplement with $5 \% \mathrm{FBS}$ for $72 \mathrm{~h}$ at $37^{\circ} \mathrm{C}$. The cells that invaded through the membrane were fixed with $3 \%$ formaldehyde for $15 \mathrm{~min}$ at $37^{\circ} \mathrm{C}$ and stained with $0.5 \%$ crystal violet for $10 \mathrm{~min}$ at $37^{\circ} \mathrm{C}$. The invasion and migration of tumor cells were assessed in a minimum of three randomly selected fields using an inverted microscope (Olympus BX51; Olympus Corporation, Tokyo, Japan).

Western blot analysis. MCF-7 cells were harvested by scraping and were subsequently lysed in radioimmunoprecipitation buffer (Sigma-Aldrich; Merck KGaA, Darmstadt, Germany) followed by homogenization at $4^{\circ} \mathrm{C}$ for $10 \mathrm{~min}$. Protein concentration was measured by a BCA protein assay kit (Thermo Scientific, Pittsburgh PA, USA). Protein (20 $\mu \mathrm{g})$ was analyzed using $12 \%$ SDS-PAGE and then transferred onto a polyvinylidene fluoride membrane (EMD Millipore, Billerica, MA, USA). The membranes were incubated in blocking buffer (5\% milk) for $2 \mathrm{~h}$ at $37^{\circ} \mathrm{C}$ prior to incubation with primary antibodies at $4^{\circ} \mathrm{C}$ overnight. Proteins were incubated with rabbit anti-human Big-h3 (cat no. ab170874, 1:1,000 dilution, Abcam, Cambridge, MA, USA), PI3K (cat no. ab86714, 1:1,000 dilution, Abcam), pAKT (cat no. ab81283, 1:1,000 dilution, Abcam), Akt (cat no. ab8805, 1:1,000 dilution, Abcam) and $\beta$-actin (1:2,000 dilution, cat no. ab5694; Abcam, Cambridge, UK) antibodies for $12 \mathrm{~h}$ at $4^{\circ} \mathrm{C}$. Proteins were the incubated with horseradish peroxide (HRP)-labeled secondary goat anti-rabbit antibodies (1:5,000 dilution, ab205718, Abcam) for $2 \mathrm{~h}$ at $37^{\circ} \mathrm{C}$ and protein expression was analyzed using a chemiluminescence detection system (Version 3.0, Sigma-Aldrich, Merck KGaA). The density of the bands was analyzed by Quantity One software (version 4.62, Bio-Rad Laboratories, Inc., Hercules, CA, USA).

Animal study. A total of 30 specific pathogen-free (SPF) female nude Balb/c mice (6-8 weeks old) were purchased from Shanghai Laboratory Animal Center (Shanghai, China). All rats were housed in a temperature-controlled facility at 
$23 \pm 1^{\circ} \mathrm{C}$ with a relative humidity of $50 \pm 5 \%$ and were exposed to a 12-h light/dark cycle. The mammary glands of mice were subcutaneously implanted with $\beta$ ig-h3-overexpressed, si-Rßig-h3-treated or si-Rvector-transfected MCF-7 cells $\left(1 \times 10^{7}\right)$ and were subsequently divided into three groups $(\mathrm{n}=10$ in each group). Mice were observed for 40 days following tumor inoculation. Tumor diameters were recorded every 2 days and tumor volume was calculated using the following formula: $0.52 \times$ smallest diameter ${ }^{2} \mathrm{x}$ largest diameter (17). Experimental mice were euthanized when the tumor diameter reached $10 \mathrm{~mm}$. The present study was performed in strict accordance with the recommendations in the Guide for the Care and Use of Laboratory Animals of China (18). The present study was also approved by the Ethics Committee of Pingdu People's Hospital (Qingdao, China). All surgery was performed following intraperitoneal injection of sodium pentobarbital (40 mg/kg, Sigma-Aldrich; Merck KGaA, Darmstadt, Germany) to induce anesthesia and all efforts were made to minimize suffering.

Tumor metastasis assay. Animals were euthanized by overdose with pentobarbital (intraperitoneal, $120 \mathrm{mg} / \mathrm{kg}$ ) on day 40 . Mice were dissected and the distribution of the tumor mass was observed in the lung, liver, bowel, bone, brain and pleura. The tumor metastasis rate was recorded in each group $(n=6)$ according to the numbers of tumors as described previously (19).

Immunohistochemistry. Tumor tissues from xenografted mice were fixed using $10 \%$ formaldehyde for $30 \mathrm{~min}$ at $37^{\circ} \mathrm{C}$, washed with PBS and followed with embedding in paraffin wax. Tissues were deparaffinized in xylene and rehydrated in grade alcohols. They were then cut into $4-\mu \mathrm{m}$ thick serial sections. Antigen retrieval was then performed on tumor sections using Antigen Retrieval Reagents (cat. no. \#CTS015, Bio-Rad Laboratories, Inc.). Tumor sections were blocked with 5\% milk for $2 \mathrm{~h}$ at $37^{\circ} \mathrm{C}$ and then incubated with goat anti-human $\beta$ ig-h3 (cat no. ab170874, 1:1,000 dilution), PI3K (1:1,000 dilution, cat no. ab86714) pAKT (cat no. ab81283, 1:1,000 dilution) or Akt (1:1,000 dilution, cat no. ab8805; all Abcam) antibody for $12 \mathrm{~h}$ at $37^{\circ} \mathrm{C}$. Sections were then incubated with HRP-labeled secondary goat anti-rabbit antibodies (1:2,000 dilution, ab150077, Abcam) and visualized using ZEISS LSM 510 confocal microscope at a magnification of $\mathrm{x} 40$.

Statistical analysis. All data are expressed as the mean \pm standard deviation of triplicate dependent experiments. The results were analyzed using Student's t test or one-way analysis of variance followed by a Tukey's honest significant difference test. All data were analyzed using SPSS Statistics 19.0 (IBM Corp., Armonk, NY, USA) and Graphpad Prism version 5.0 (GraphPad Software, Inc., La Jolla, CA, USA), as well as Microsoft Excel (version 2010, Microsoft Corporation, Redmond, WA, USA). $\mathrm{P}<0.05$ was determined to indicate statistically significant difference.

\section{Results}

Effects of $\beta$ ig-h 3 on breast carcinoma cell growth. The expression of $\beta$ ig-h3 was analyzed in the breast cancer cell lines MCF-7, BT474 and SKBR3 and in the normal breast cell line MCF-10A, which acted as the control. The expression of $\beta$ ig-h3 was significantly increased in MCF-7, BT474 and SKBR3 cells compared with MCF-10A cells (Fig. 1A). It was also demonstrated that $\mathrm{p} \beta \mathrm{ig}-\mathrm{h} 3$ promoted $\beta$ ig-h3 expression, while si-R $\beta$ ig- $\mathrm{h} 3$ decreased $\beta$ ig-h 3 expression in MCF-7, BT474 and SKBR3 cells (Fig. 1B). The results also demonstrated that $\beta$ ig-h3 transfection significantly promoted the growth of MCF-7, BT474, SKBR3 and MCF-10A cells compared with their vector transfection controls (Fig. 1C). However, knockdown of $\beta$ ig-h3 expression by si-R $\beta$ ig-h3 significantly inhibited the growth of MCF-7, BT474 and SKBR3 cells compared with the controls transfected with si-R vector (Fig. 1D). These results suggest that $\beta$ ig-h3 promotes the growth of breast carcinoma cells.

Transfection of $\beta i g-h 3$ promotes the migration and invasion of breast carcinoma cells. The effects of $\beta$ ig-h 3 on the migration and invasion of breast carcinoma cells were investigated in MCF-7 cells following transfection. The results demonstrated that the migration and invasion ability of MCF-7 cells was significantly increased in cells transfected with p $\beta$ ig-h3 compared with control cells (Fig. 2A and B). By contrast, knockdown of $\beta$ ig-h3 by si-R $\beta i g-h 3$ significantly inhibited the migration and invasion of MCF-7 cells (Fig. 2C and D). These results suggest that $\beta$ ig- $\mathrm{h} 3$ promotes the migration and invasion of breast carcinoma cells.

Transfection of $\beta$ ig-h3 inhibits the apoptosis of breast carcinoma cells induced by cisplatin. Following transfection, the apoptosis of breast carcinoma cells was analyzed by incubation with cisplatin. The apoptosis rate of MCF-7 cells was significantly suppressed in cells transfected with $\mathrm{p} \beta$ ig-h3 compared with the control (Fig. 3A). By contrast, knockdown of $\beta$ ig-h3 by si-Rßig-h3 significantly promoted the apoptosis of MCF-7 cells induced by cisplatin compared with the control (Fig. 3B). These results indicate that $\beta$ ig-h3 expression is associated with the apoptosis of breast carcinoma cells induced by cisplatin.

Knockdown of $\beta i g-h 3$ inhibits the growth and aggressiveness of breast carcinoma cells via the PI3K/Akt signaling pathway. It was subsequently determined whether $\beta$ ig-h3 promotes the growth, migration and invasion of breast carcinoma cells via the PI3K/Akt signaling pathway. The results indicated that the expression of PI3K and Akt was significantly increased in MCF-7 cells transfected with pßig-h3 compared with controls (Fig. 4A). By contrast, the expression of PI3K and Akt was significantly decreased in MCF-7 cells transfected with si-R $\beta$ ig-h3 compared with the control (Fig. 4B). The results also demonstrated that PI $3 \mathrm{~K}$ upregulation reversed the effects of si-R $\beta i g-h 3$ on the expression of Akt in MCF-7 cells (Fig. 4C). In addition, PI3K upregulation reversed the effects of si-R $\beta i g-h 3$ on the growth, migration and invasion of MCF-7 cells (Fig. 4D-F). These data suggest that $\beta$ ig-h3 promotes the growth and metastasis of breast carcinoma cells via the PI3K/Akt signaling pathway.

Knockdown of Big-h3 suppresses the formation of breast tumor masses in xenografted mice. The role of $\beta$ ig-h 3 in the formation of breast carcinoma was investigated by implanting

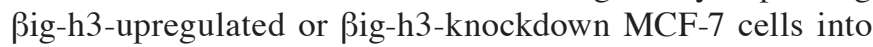


A

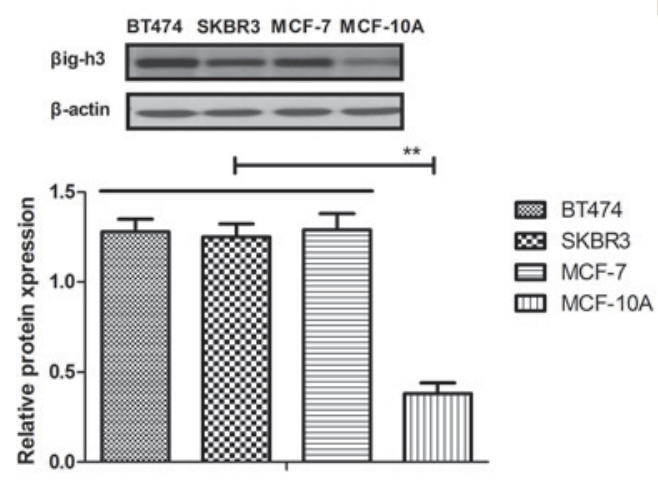

C

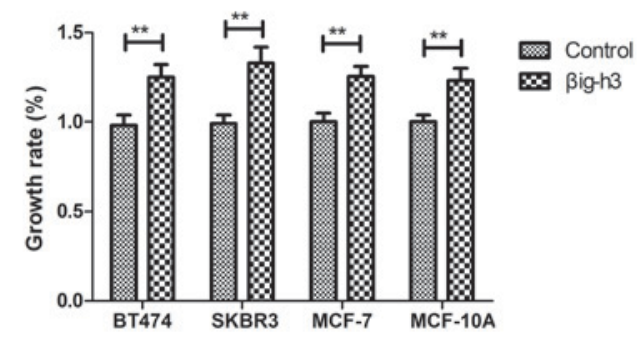

B

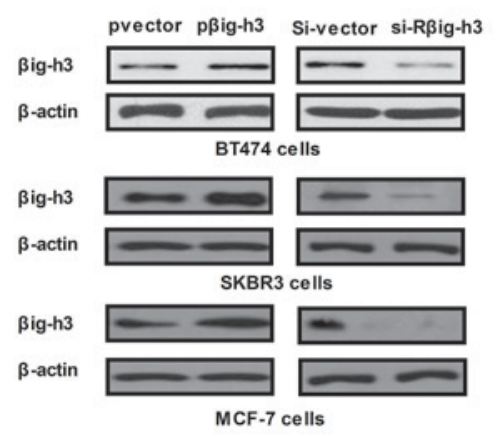

D

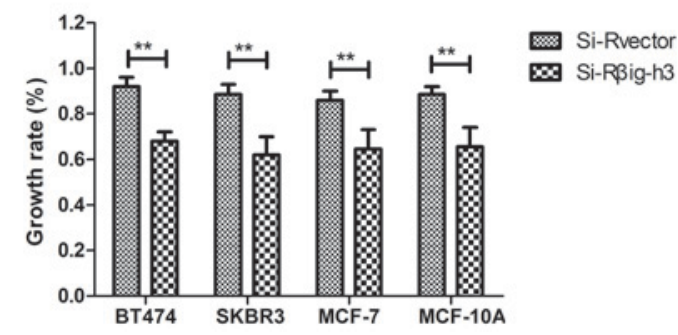

Figure 1. $\beta$ ig-h3 promotes the growth of breast carcinoma cells. (A) $\beta$ ig-h3 expression in the breast cancer cell lines MCF-7, BT474, SKBR3 and the normal breast cell line MCF-10A was determined using western blotting. (B) The expression of $\beta$ ig-h3 in MCF-7, BT474 and SKBR3 cells transfected with pvector, p $\beta$ ig-h3, si-vector or si-Rßig-h3 was determined using western blotting. (C) The effect of $\beta$ ig-h3 upregulation on MCF-7, BT474 and SKBR3 cell growth was determined using an MTT assay. (D) Effect of Big-h3 knockdown on MCF-7, BT474 and SKBR3 cell growth was determined using an MTT assay. Values are presented as the mean \pm standard error of the mean of three independent experiments performed in triplicate. ${ }^{* *} \mathrm{P}<0.01$. $\beta$ ig-h3, $\beta$-inducible gene-h3; si-R, small interfering RNA.

experimental mice. The results demonstrated that tumor weight in the si-Rßig-h3 group was significantly decreased compared with the control and p $\beta$ ig-h3 groups, suggesting that $\beta$ ig-h3 knockdown inhibits the formation of breast tumor masses. By contrast, tumor weight in the pßig-h3 group was significantly increased compared with the control, indicating that $\beta$ ig-h3 upregulation promotes the growth of breast tumors (Fig. 5A). It was also determined that the metastasis rate was significantly decreased in the si-R $\beta$ ig-h3 group compared with the control and $\mathrm{p} \beta$ ig-h3 groups, suggesting that $\beta$ ig-h3 knockdown inhibits breast carcinoma metastasis compared with the control (Fig. 5B). By contrast, $\beta$ ig-h3-upregulation significantly promoted breast carcinoma metastasis in the subcutaneous tissue of experimental mice, suggesting that $\beta$ ig-h3 upregulation stimulates carcinoma metastasis. Immunohistochemistry analysis indicated that the expression of $\beta$ ig-h3, PI3K and Akt were markedly increased in $\beta$ ig-h3-overexpressed breast tumors, while PI3K and Akt expression were markedly decreased in MCF-7 breast tumors following $\beta$ ig-h3 knockdown (Fig. 5C). The expression of phosphorylated Akt was also downregulated following Big-h3-knockdown in MCF-7 breast tumors (Fig. 5D). These results therefore suggest that $\beta$ ig-h3 knockdown suppresses the formation of breast tumor masses in vivo.

\section{Discussion}

The number of women that are diagnosed with breast cancer had increased since 2010, and the majority receive breast-conserving surgery followed by adjuvant radiotherapy, chemotherapy and/or comprehensive treatment (20). The results of previous studies have suggested that increased $\beta$ ig-h3 expression promotes migration and invasion in different types of human cancer cells, including intraductal carcinoma cells, breast mucinous adenocarcinoma cells and medullary breast carcinoma cells $(8,12,13)$. However, the role of $\beta$ ig-h3 in the progression of human breast cancer remains unknown. The present study investigated the effects of $\beta$ ig-h3 on the growth, migration, invasion and apoptosis of human breast cancer cells. The association between the $\beta$ ig-h3-mediated PI3K/Akt signaling pathway, and cell growth, invasion and migration in human breast cancer cells was also assessed. The results suggested that $\beta$ ig-h3 upregulation promotes the growth and invasion of breast cancer cells, whereas $\beta$ ig-h3 knockdown inhibits the growth and invasion of breast cancer cells via downregulation of the PI3K/Akt signaling pathway, which also decreases the resistance of breast carcinoma cells to apoptosis following its induction by cisplatin.

Big-h3 is a protein that serves a role in the proliferation, migration, apoptosis and differentiation of tumor cells (14). It has been suggested that $\beta$ ig-h3 promotes carcinogenesis in different types of cancer (21). In addition, Kim et al (22) demonstrated that $\beta$ ig-h3 interacts with $\alpha 3 \beta 1$ integrin to promote the adhesion and migration of human hepatoma cells by activating focal adhesion kinase-paxillin signaling. Furthermore, $\beta$ ig-h 3 promotes the adhesion, migration and proliferation of gastric cancer cells in peritoneal 
A
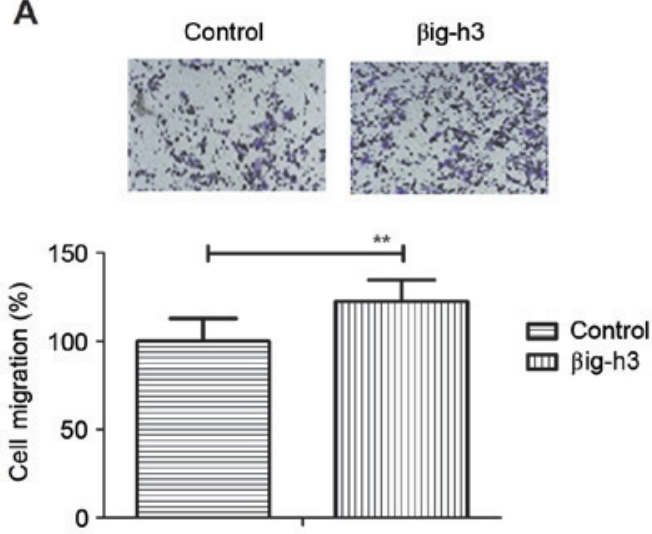

C

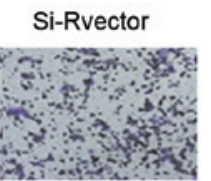

Si-R $\beta$ ig-h3
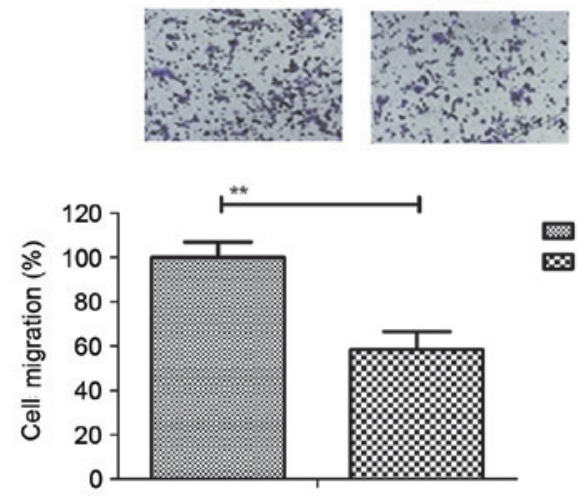

B
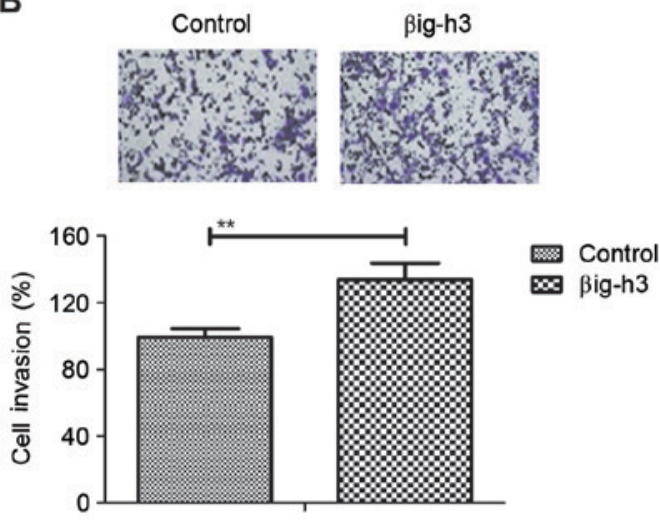

D
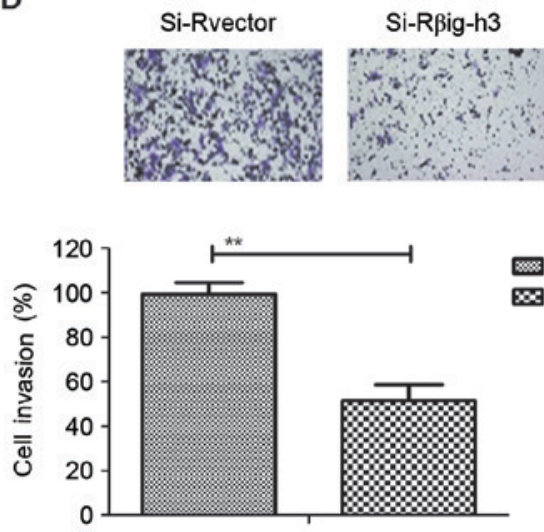

Si-Rvector

$\infty$ Si-R $\beta$ ig-h3

Figure 2. Upregulation of $\beta$ ig-h3 promotes the migration and invasion of breast carcinoma cells. Upregulation of $\beta$ ig-h3 significantly promotes the (A) migration and (B) invasion of MCF-7 cells compared with the control. Knockdown of ßig-h3 significantly inhibits MCF-7 cell (C) migration and (D) invasion following $72 \mathrm{~h}$ incubation in vitro compared with the control. Magnification, $\mathrm{x} 40$. Values are presented as the mean \pm standard error of the mean of three independent experiments performed in triplicate. ${ }^{* *} \mathrm{P}<0.01$. $\beta$ ig-h3, $\beta$-inducible gene-h3; si-R, small interfering RNA.

A

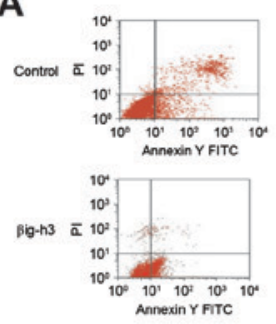

$\infty$
$\times$ Si-Rvector

Figure 3. Transfection of $\beta$ ig-h3 suppresses the apoptosis of breast carcinoma cells induced by cisplatin. (A) Upregulation of $\beta$ ig-h3 decreases the apoptotic rate of MCF-7 cells compared with the control following $48 \mathrm{~h}$ incubation, as determined using flow cytometry. (B) $\beta$ ig-h3 knockdown promotes the apoptosis of MCF-7 cells compared with the control following $48 \mathrm{~h}$ incubation, as determined using flow cytometry. Values are presented as the mean \pm standard error of the mean of three independent experiments performed in triplicate. ${ }^{* *} \mathrm{P}<0.01$. $\beta$ ig-h3, $\beta$-inducible gene-h3; si-R, small interfering RNA; FITC, fluorescein isothiocyanate; PI, propidium iodide.

carcinomatosis $(8,22)$. Jeong and Kim (23) demonstrated that transforming growth factor- $\beta 1$ enhances $\beta$ ig-h3-mediated gastrointestinal tract tumorigenesis migration via the FAK/Akt/Akt1S1/PRS6/EIF4EBP pathways. The results of the present study indicated that $\beta$ ig-h3 knockdown inhibited the growth, migration and invasion of breast carcinoma cells via the PI3K/Akt signaling pathway. In addition, it was indicated that the upregulation of $\beta$ ig-h3 promotes the growth, migration and invasion of breast cancer cells and also increases apoptotic resistance in breast cancer cells.
B

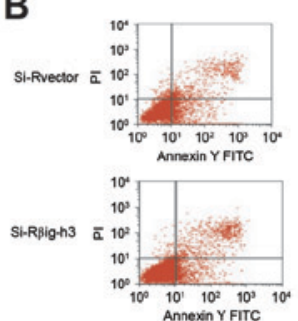

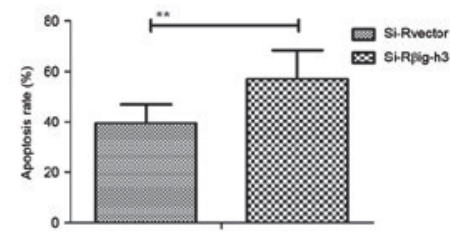

In conclusion, the results of the current study indicate that $\beta$ ig-h3 is associated with the growth and metastasis of breast cancer cells. The data suggest that the inhibition of PI3K and Akt expression induced by $\beta$ ig-h3 is associated with the growth, apoptosis and metastasis of breast cancer cells. Additionally, $\beta$ ig-h3 knockdown inhibits the proliferation and increases the apoptosis of breast carcinoma cells. These results imply that the decreased expression of $\beta$ ig-h3 decreases the risk of metastasis in patients with breast cancer, whereas the increased expression of $\beta$ ig-h3 may require 
A
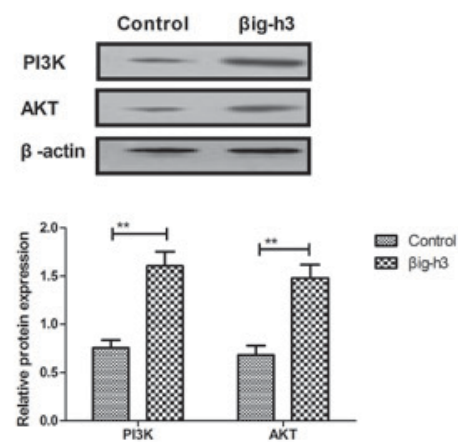

D

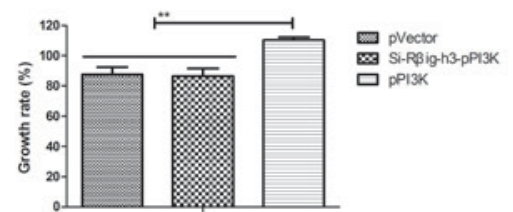

B
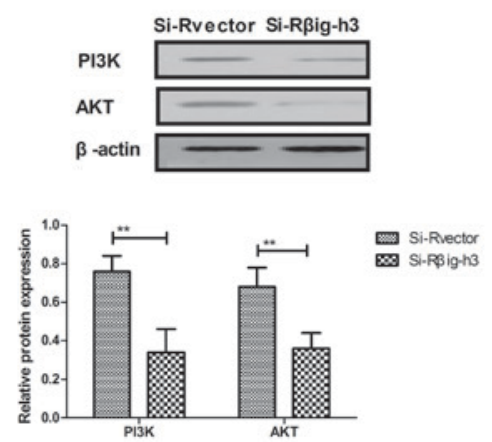

E

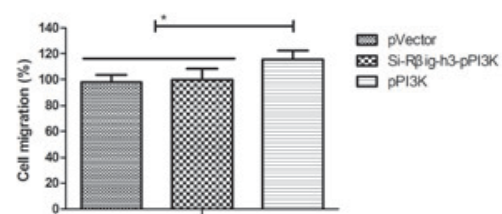

C
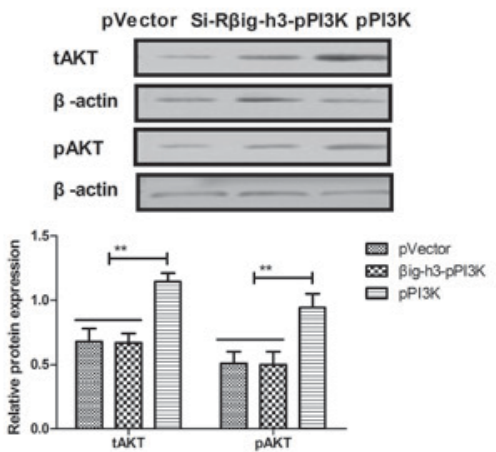

$\mathbf{F}$

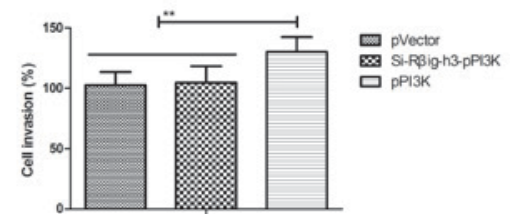

Figure 4. Transfection of $\beta$ ig-h3 regulates the growth, migration and invasion of breast carcinoma cells via the PI3K/Akt signaling pathway. (A) Upregulation of $\beta$ ig-h3 increases the expression of PI3K and Akt in MCF-7 cells compared with the control. (B) Knockdown of $\beta$ ig-h3 decreases PI3K and Akt expression in MCF-7 cells compared with the control following $72 \mathrm{~h}$ incubation. (C) PI3K upregulation reverses ßig-h3-enhanced Akt expression and phosphorylation in MCF-7 cells. PI3K upregulation reverses the si-Rßig-h3-inhibited (D) growth, (E) migration and (F) invasion in MCF-7 cells. Values are presented as the mean \pm standard error of the mean of three independent experiments performed in triplicate. ${ }^{*} \mathrm{P}<0.05,{ }^{* * *} \mathrm{P}<0.01$. $\beta$ ig-h3, $\beta$-inducible gene-h3; PI3K, phosphatidylinositol 3-kinase; Akt, protein kinase B; si-R, small interfering RNA; p, phosphorylated.

A

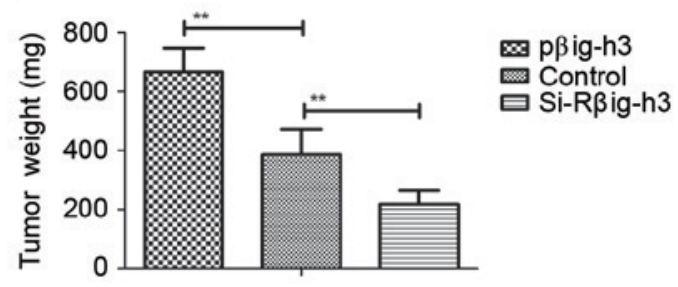

C

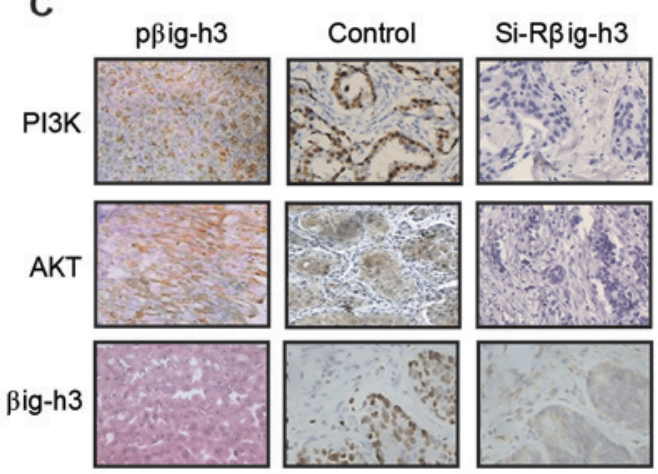

B

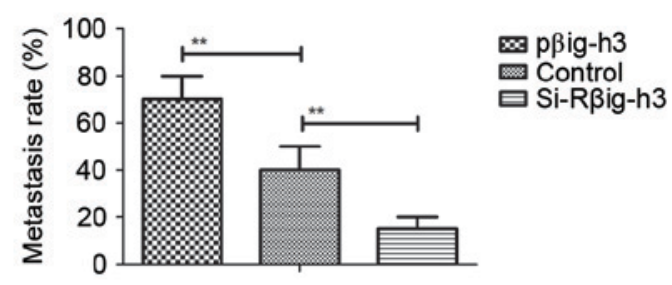

D

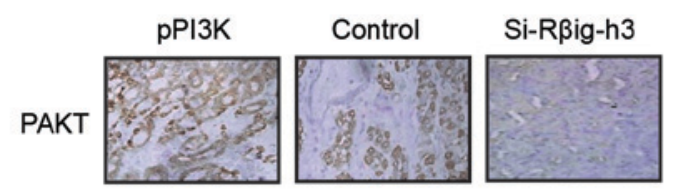

Figure 5. ßig-h3 knockdown suppresses the formation of breast tumor mass and carcinoma metastasis in xenografted mice. (A) Tumor weight in the $\mathrm{p} \beta$ ig-h3,

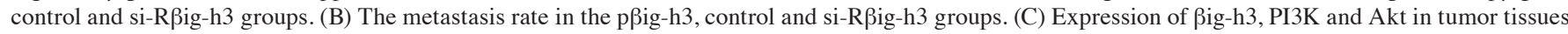

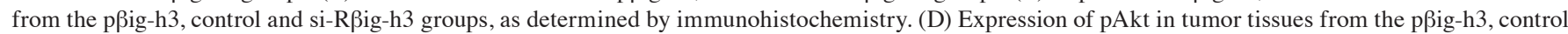
and si-R $\beta$ ig-h3 groups, as determined by immunohistochemistry. Magnification, $\mathrm{x} 40$. Values are presented as the mean \pm standard error of the mean of three independent experiments performed in triplicate. ${ }^{* *} \mathrm{P}<0.01$. $\beta i \mathrm{~g}-\mathrm{h} 3, \beta$-inducible gene-h3; PI3K, phosphatidylinositol 3-kinase; Akt, protein kinase B; si-R, small interfering RNA; p, phosphorylated.

the administration of intensive adjuvant chemotherapy to patients. It may therefore be advantageous to tailor therapy to individual patients, according to levels of $\beta$ ig-h3 expression, as higher $\beta$ ig-h3 expression seems to increase the risk of metastasis. The results indicate that $\beta$ ig-h3 is a potential molecular target for breast carcinoma treatment, which may contribute to understanding of the mechanism of human breast carcinoma metastasis. 


\section{References}

1. Benson R, Madan R, Julka PK and Rath GK: Metaplastic carcinoma of breast: A case series of seven patients from a tertiary care center and review of literature. Gulf J Oncolog 1: 74-76, 2016.

2. Conlon N, Sadri N, Corben AD and Tan LK: Acinic cell carcinoma of breast: Morphologic and immunohistochemical review of a rare breast cancer subtype. Hum Pathol 51: 16-24, 2016.

3. Conlon N, Howard J, Catalano J, Gallagher M, Tan LK and Corben AD: Breast carcinoma in young women: No evidence of increasing rates of metastatic breast carcinoma in a single tertiary center review. Breast J 22: 287-292, 2016.

4. Ziyadi M, Boujoual M, Raiteb H, Babahabib MA, Kouach J, Moussaoui DR and Dehayni M: Squamous cell carcinoma of the breast: Report of a case and review of the literature. Pan Afr Med J 24: 213, 2016.

5. Zagelbaum NK, Ward MF II, Okby $\mathrm{N}$ and Karpoff $\mathrm{H}$ : Invasive ductal carcinoma of the breast with osteoclast-like giant cells and clear cell features: A case report of a novel finding and review of the literature. World J Surg Oncol 14: 227, 2016.

6. Modesto A, Gandy C, Mery E, Filleron T, Massabeau C, Izar F, Charitansky H, Roché $\mathrm{H}$ and de Lafontan B: Breast ductal carcinoma in situ with microinvasion: Pathological review and clinical implications. Cancer Radiother 18: 107-110, 2014 (In French).

7. Falco G, Buggi F, Sanna PA, Dubini A and Folli S: Breast metastases from a renal cell carcinoma. A case report and review of the literature. Int J Surg Case Rep 5: 193-195, 2014.

8. Li Z, Miao Z, Jin G, Li X, Li H, Lv Z and Xu HM: ßig-h3 supports gastric cancer cell adhesion, migration and proliferation in peritoneal carcinomatosis. Mol Med Rep 6: 558-564, 2012.

9. Shao G, Berenguer J, Borczuk AC, Powell CA, Hei TK and Zhao Y: Epigenetic inactivation of Betaig-h3 gene in human cancer cells. Cancer Res 66: 4566-4573, 2006.

10. Zhao Y, El-Gabry M and Hei TK: Loss of Betaig-h3 protein is frequent in primary lung carcinoma and related to tumorigenic phenotype in lung cancer cells. Mol Carcinog 45: 84-92, 2006.

11. Schneider D, Kleeff J, Berberat PO, Zhu Z, Korc M, Friess H and Büchler MW: Induction and expression of betaig-h3 in pancreatic cancer cells. Biochim Biophys Acta 1588: 1-6, 2002.

12. Wang F, Li XW, Lu WB and Jin JH: betaig-h3 correlates with related factors of peritoneal metastasis of gastric cancer. J Biol Regul Homeost Agents 29: 181-186, 2015.

13. Ween MP, Oehler MK and Ricciardelli C: Transforming growth factor-beta-induced protein (TGFBI)/(betaig-H3): A matrix protein with dual functions in ovarian cancer. Int J Mol Sci 13: 10461-10477, 2012.
14. Ma C, Rong Y, Radiloff DR, Datto MB, Centeno B, Bao S, Cheng AW, Lin F, Jiang S, Yeatman TJ and Wang XF: Extracellular matrix protein betaig-h3/TGFBI promotes metastasis of colon cancer by enhancing cell extravasation. Genes Dev 22: 308-321, 2008.

15. Guo L, Wu H, Zhu J, Zhang C, Ma J, Lan J and Xie X: Genetic variations in the PI3K/AKT pathway predict platinum-based neoadjuvant chemotherapeutic sensitivity in squamous cervical cancer. Life Sci 143: 217-224, 2015.

16. Komeili-Movahhed T, Fouladdel S, Barzegar E, Atashpour S, Hossein Ghahremani M, Nasser Ostad S, Madjd Z and Azizi E: PI3K/Akt inhibition and down-regulation of BCRP re-sensitize MCF7 breast cancer cell line to mitoxantrone chemotherapy. Iran J Basic Med Sci 18: 472-477, 2015.

17. Zhuang T, Djemil T, Qi P, Magnelli A, Stephans K, Videtic G and Xia P: Dose calculation differences between Monte Carlo and pencil beam depend on the tumor locations and volumes for lung stereotactic body radiation therapy. J Appl Clin Med Phys 14: 4011, 2013.

18. Davey G and Wu Z: Attitudes in China toward the use of animals in laboratory research. Altern Lab Anim 35: 313-316, 2007.

19. Castillo-Pichardo L, Cubano LA and Dharmawardhane S: Dietary grape polyphenol resveratrol increases mammary tumor growth and metastasis in immunocompromised mice. BMC Complement Altern Med 13: 6, 2013.

20. Beck RE, Kim L, Yue NJ, Haffty BG, Khan AJ and Goyal S: Treatment techniques to reduce cardiac irradiation for breast cancer patients treated with breast-conserving surgery and radiation therapy: A review. Front Oncol 4: 327, 2014.

21. Ma J, Cui W, He SM, Duan YH, Heng LJ, Wang L and Gao GD: Human U87 astrocytoma cell invasion induced by interaction of $\beta$ ig-h3 with integrin $\alpha 5 \beta 1$ involves calpain- 2 . PLoS One 7: e37297, 2012.

22. Kim YH, Kwon HJ and Kim DS: Matrix metalloproteinase 9 (MMP-9)-dependent processing of $\beta$ ig-h3 protein regulates cell migration, invasion, and adhesion. J Biol Chem 287: 38957-38969, 2012.

23. Jeong HW and Kim IS: TGF-betal enhances betaig-h3-mediated keratinocyte cell migration through the alpha3betal integrin and PI3K. J Cell Biochem 92: 770-780, 2004.

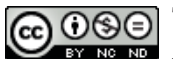

This work is licensed under a Creative Commons Attribution-NonCommercial-NoDerivatives 4.0 International (CC BY-NC-ND 4.0) License. 